\title{
Mobilization of healthy donors with plerixafor affects the cellular composition of T-cell receptor

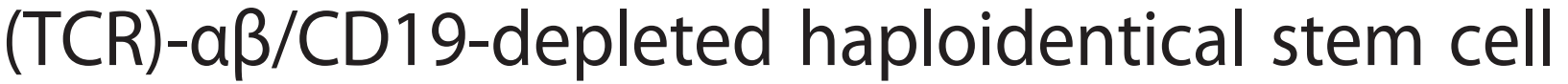 grafts
}

Sergio Rutella ${ }^{1,5^{*}}$, Perla Filippini ${ }^{1}$, Valentina Bertaina ${ }^{1}$, Giuseppina Li Pira ${ }^{1}$, Lidia Altomare ${ }^{1}$, Stefano Ceccarelli ${ }^{1}$, Letizia P Brescia', Barbarella Lucarelli ${ }^{1}$, Elia Girolami ${ }^{1}$, Gianpiero Conflitti ${ }^{1}$, Maria Giuseppina Cefalo ${ }^{1}$, Alice Bertaina ${ }^{1}$, Tiziana Corsetti ${ }^{2}$, Lorenzo Moretta ${ }^{3,4}$ and Franco Locatelli ${ }^{1,4}$

\begin{abstract}
Background: HLA-haploidentical hematopoietic stem cell transplantation (HSCT) is suitable for patients lacking related or unrelated HLA-matched donors. Herein, we investigated whether plerixafor (MZ), as an adjunct to G-CSF, facilitated the collection of mega-doses of hematopoietic stem cells (HSC) for TCR-aß/CD19-depleted haploidentical $\mathrm{HSCT}$, and how this agent affects the cellular graft composition.

Methods: Ninety healthy donors were evaluated. Single-dose MZ was given to 30 'poor mobilizers' (PM) failing to

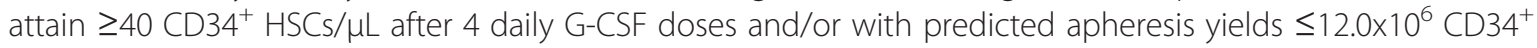
cells/kg recipient's body weight.

Results: MZ significantly increased $\mathrm{CD}_{3} 4^{+}$counts in PM. Naïve/memory T and B cells, as well as natural killer (NK) cells, myeloid/plasmacytoid dendritic cells (DCs), were unchanged compared with baseline. MZ did not further promote the G-CSF-induced mobilization of $\mathrm{CD}_{1} 6^{+}$monocytes and the down-regulation of IFN- $\gamma$ production by $\mathrm{T}$ cells. HSC grafts harvested after G-CSF + MZ were enriched in myeloid and plasmacytoid DCs, but contained low numbers of pro-inflammatory 6-sulfo-LacNAc ${ }^{+}$(Slan)-DCs. Finally, children transplanted with G-CSF + MZ-mobilized grafts received greater numbers of monocytes, myeloid and plasmacytoid DCs, but lower numbers of NK cells, NK-like T cells and Slan-DCs.
\end{abstract}

Conclusions: MZ facilitates the collection of mega-doses of $\mathrm{CD}_{3} 4^{+} \mathrm{HSC}$ for haploidentical HSCT, while affecting graft composition.

\section{Background}

HLA-haploidentical hematopoietic stem cell transplantation (HSCT) is an effective therapeutic option for patients with high-risk leukemia, and without human leukocyte antigen (HLA)-matched donors [1]. Historically, clinical success, i.e., full donor-type engraftment in 95\% of patients with acute leukemia and negligible incidence of acute and chronic graft-versus-host disease

\footnotetext{
* Correspondence: sergio.rutella@gmail.com

'Department of Pediatric Hematology/Oncology and Transfusion Medicine, IRCCS Bambino Gesù Children's Hospital, Rome, Italy

${ }^{5}$ Current address: Division of Translational Medicine, Research Branch, Sidra Medical \& Research Centre, Doha, Qatar

Full list of author information is available at the end of the article
}

(GVHD), has been achieved with T-cell depleted (TCD) grafts containing a mega-dose of positively selected $\mathrm{CD}^{+} 4^{+}$cells, without the use of any post-transplant immunosuppression [2].

Granulocyte colony-stimulating factor (G-CSF) is widely employed as mobilizing agent in healthy donors and cancer patients. However, G-CSF-based regimens are associated with a 5-30\% failure rate [3]. The bicyclam AMD3100, also known as plerixafor, was approved in 2008 for use in combination with G-CSF to mobilize hematopoietic stem cells (HSC) for autologous HSCT [4]. Plerixafor (Mozobil ${ }^{\circ}$, MZ) specifically and reversibly blocks the binding of $\mathrm{C}-\mathrm{X}-\mathrm{C}$ chemokine receptor 4 (CXCR4) to its natural 
ligand, stromal cell-derived factor 1 (SDF1), a CXC chemokine and key regulator of HSC homing and retention in the bone marrow (BM). We previously showed that G-CSF-mobilized peripheral blood $\mathrm{CD}_{4} 4^{+}$cells retain surface CXCR4 [5], implying that BM microenvironment might easily accommodate immigrating progenitor cells that express high levels of CXCR4 following G-CSF mobilization or stress conditions. MZ synergizes with G-CSF through its different mechanism of action, as suggested by randomized phase III studies, where plerixafor and G-CSF were shown to be superior to G-CSF alone for CD34 ${ }^{+}$HSC mobilization and collection [6,7].

Dendritic cells (DCs) are professional antigen-presenting cells triggering primary adaptive immune responses through the activation of naïve $\mathrm{CD} 4^{+}$and $\mathrm{CD} 8^{+} \mathrm{T}$ cells [8]. Initially, human DCs were categorized into type 1 (DC1) and type 2 DCs (DC2), which are functionally distinguished by pattern of cytokine production and T-cell driving capacity. Recently, 3 cell types assigned to the DC lineage have been characterized in human blood, i.e., type 1 myeloid DCs (MDC1), type 2 myeloid DCs (MDC2) and plasmacytoid DCs [9-11]. Blood CD1c ${ }^{+}$ MDC1 efficiently cross-present soluble antigens and prime cytotoxic T cells [12]. Human $\mathrm{BDCA}-3^{+} \mathrm{MDC} 2$ share some characteristics with murine $\mathrm{CD} 8 \alpha^{+} \mathrm{DCs}$, such as production of high amounts of IL-12p70 and interferon (IFN) $-\lambda[10,11]$. By contrast, human plasmacytoid DCs secrete IFN- $\alpha$ and activate natural killer (NK) cells, macrophages and myeloid DCs to mount immune responses against microbial products.

There is growing evidence that the biological activities of G-CSF are not limited only to the myeloid lineage, but extend to other cell types mediating, amongst the others, inflammation, immunity and angiogenesis $[13,14]$. Initial studies in mice supported a role for G-CSF in immune skewing towards $\mathrm{T}$ helper type 2 (Th2) cytokine production [15]. In humans, G-CSF increases IL-4 release and decreases IFN- $\gamma$ secretion [16], and promotes the differentiation of transforming growth factor- $\beta 1 / \mathrm{IL}-10$ producing type 1 regulatory T cells (Treg), which are endowed with the ability to suppress T-cell proliferation in a cytokine-dependent manner $[17,18]$. Finally, G-CSF indirectly modulates DC function, by inducing hepatocyte growth factor, IL-10 and IFN- $\alpha$, and mobilizes DC2 [19-21].

Currently, the use of MZ in healthy donors is offlabel, with anecdotal reports describing its 'just-in-time' application either as single agent or after mobilization failure with G-CSF [22-24]. The few available data on immunological effects of MZ are mostly limited to cancer patients and show that $\mathrm{CD} 8^{+} \mathrm{T}$-cell release of IFN- $\gamma$ and TNF- $\alpha$ may be higher in autologous grafts collected after G-CSF and MZ, compared with G-CSF alone [25].
We recently developed a novel graft manipulation strategy aimed at extensively removing $\mathrm{T}$-cell receptor (TCR) $-\alpha \beta^{+} \mathrm{T}$ cells and CD19 $\mathrm{B}$ cells from haploidentical HSCs, prior to their infusion into children with nonmalignant disorders [26]. TCR- $\alpha \beta$ and B-cell depletion is intended to prevent GVHD and post-transplantation lymphoproliferative disorders, respectively. The present study was designed and conducted to investigate whether and to what extent the administration of MZ, an 'immediate salvage' strategy in donors with suboptimal CD34-cell counts after standard-dose G-CSF, affects the cellular composition of the graft in the setting of TCR- $\alpha \beta / C D 19$-depleted haploidentical HSCT for children with hematological disorders.

\section{Methods}

\section{Donor eligibility and treatment plan}

Ninety healthy HLA-haploidentical parents of children with hematological disorders were enrolled in the present study. Our treatment algorithm is detailed in Figure 1. Donors received MZ on a compassionate basis, outside the approved label of the drug, after providing written informed consent. The study was reviewed and approved by the Institutional Ethics Committee (protocol \#938-LB). We opted for an 'immediate salvage' strategy administering $0.24 \mathrm{mg} / \mathrm{kg} \mathrm{MZ}$ to donors failing to achieve the predefined cutoff of $\geq 40 \mathrm{CD} 34^{+} \mathrm{HSCs} / \mu \mathrm{L}$ of blood after 4 daily split-doses of $12 \mu \mathrm{g} / \mathrm{kg}$ G-CSF (Figure 1A) and/or donors with suboptimal predicted apheresis yields on the expected day of HSC collection $\left(\leq 12 \times 10^{6} \mathrm{CD} 34^{+} \mathrm{HSCs} / \mathrm{kg}\right.$ of recipient's body weight; Figure 1B) [27]. MZ was administered at 12:00 PM (day +4$)$ and leukapheresis was performed on day +5 , following the morning dose of G-CSF (i.e., 9 hours after $\mathrm{MZ}$ injection). Peripheral blood was collected prior to G-CSF (day 0) and at peak CD34 $4^{+}$-cell counts (days +4 and +5 ). Normal BM samples were collected from 10 consented donors performing BM donation under general anesthesia for matched-sibling HSCT.

\section{Antibodies and reagents}

FITC-conjugated anti-IFN- $\gamma$, PE-conjugated anti-IL-17A, PerCP-Cy5.5-conjugated anti-CD4 and APC-conjugated anti-IL-4 monoclonal antibodies (mAbs; Human Th1/ Th2/Th17 Phenotyping Kit), Lineage Cocktail-1 (a mixture of FITC-conjugated mAbs directed against CD3, CD14, CD16, CD19, CD20 and CD56), BD ${ }^{\text {th }}$ Stem Cell Enumeration $\mathrm{Kit}^{\mathrm{tm}}$, mAbs directed against human CD14, CD16, CD45RO, CD62L, CD19, IgD, CD27 and CD184 (12G5 clone), Cytofix/Cytoperm ${ }^{\text {Tx }}$ solution and Golgi Plug Protein Transport Inhibitor ${ }^{\text {Tw }}$ were purchased from BD Biosciences (Mountain View, CA). 6-sulfo-LacNAc ${ }^{+}$(Slan)-DCs were identified using a PE-conjugated anti-M-DC8 mAb (DD-1 clone; Miltenyi Biotec, Bologna, Italy). 

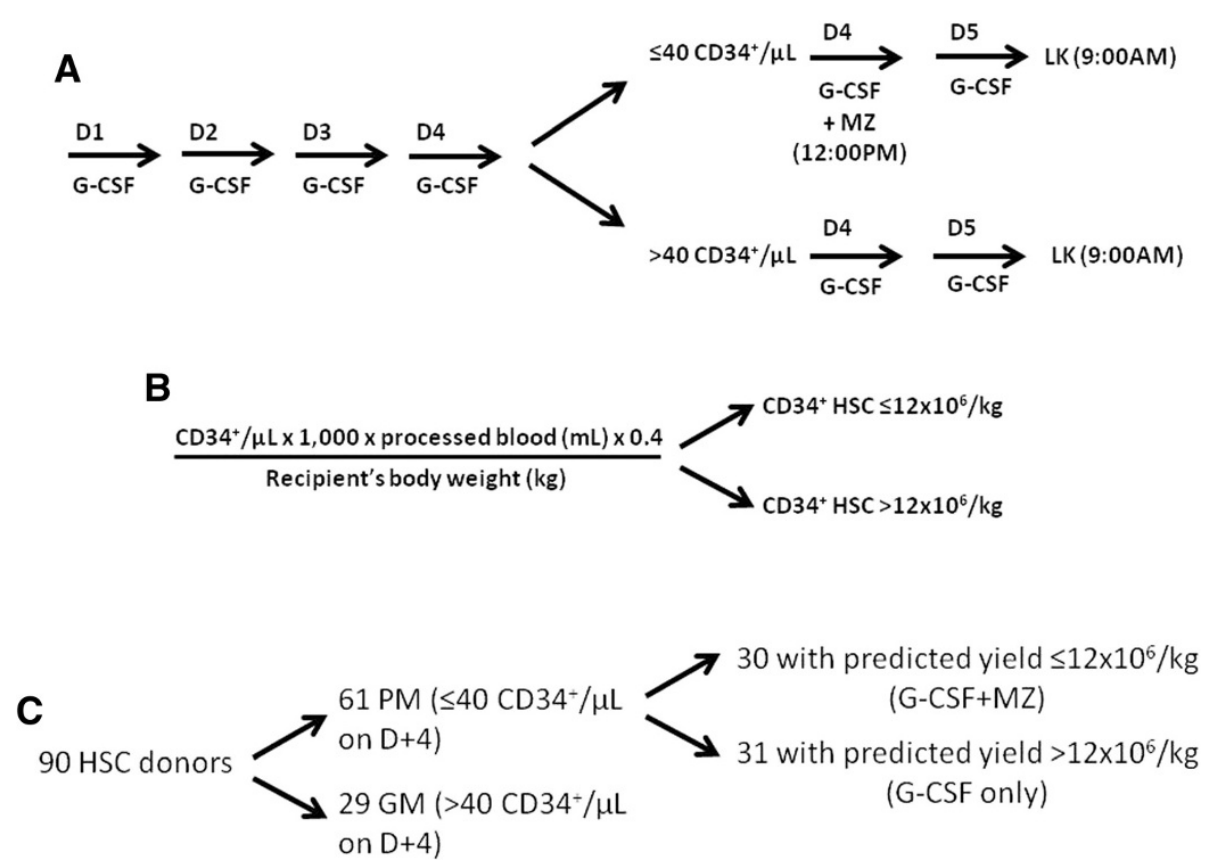

Figure $1 \mathrm{CD}^{+} 4^{+}$HSC mobilization algorithm. G-CSF was given subcutaneously at $12 \mu \mathrm{g} / \mathrm{kg}$ of body weight (divided into 2 doses, 12 hours apart) for 4 consecutive days (D). On day +4 , circulating HSCs were enumerated by flow cytometry, as detailed in Materials and Methods. Panels $\mathbf{A}$ and $\mathbf{B}$ : If donors had $\leq 40 \mathrm{CD} 34^{+}$cells $/ \mathrm{HL}$ of blood on day +4 (and/or a predicted apheresis yield $\leq 12 \times 10^{6} \mathrm{CD} 34^{+} \mathrm{HSCs} / \mathrm{kg}$ of recipient's body weight) [27], a single dose of plerixafor (MZ) was administered subcutaneously $(0.24 \mathrm{mg} / \mathrm{kg}$ of body weight), followed by HSC collection on day +5 . If donors had $>40 \mathrm{CD} 34^{+}$cells/ $\mu \mathrm{L}$ of blood on day +4 (and/or a predicted apheresis yield $>12 \times 10^{6} \mathrm{CD} 34^{+} \mathrm{HSCs} / \mathrm{kg}$ of recipient's body weight), mobilization was continued with G-CSF alone and HSCs were collected on day +5 (panel C).

Fluorochrome-conjugated mAbs directed against BDCA-1 (CD1c; AD5-8E7 clone; type 1 myeloid DCs or MDC1), BDCA-2 (CD303; AC144 clone; plasmacytoid DCs), BDCA-3 (CD141 or thrombomodulin; AD5-14H12 clone; type 2 myeloid DCs or MDC2) and BDCA-4/neuropilin-1 (CD304; AD5-17 F6 clone; plasmacytoid DCs) were from Miltenyi Biotec. Phorbol myristate acetate (PMA) and ionomycin were purchased from Sigma-Aldrich (Milan, Italy). The mAb panel and mAb combinations used for graft characterization are detailed in Table 1.

Table 1 Antibody panel used for graft characterization

\begin{tabular}{lllll}
\hline FITC & PE & Per-CP & APC & Events analyzed (\#) \\
\hline CD20 & - & CD45 & CD3 & 500,000 \\
TCR- $\gamma \delta$ & TCR-a $\beta$ & CD45 & CD3 & 500,000 \\
CD45 & CD34 & 7-AAD & - & $>100$ CD34 ${ }^{+}$events \\
CD14 & Slan-DC & - & CD16 & 50,000 \\
CD3 & CD16+CD56 & CD45 & CD19 & 50,000 \\
CD8 & CD4 & CD45 & CD3 & 50,000 \\
Lineage 1 & BDCA-4 & - & BDCA-2 & 50,000 \\
Lineage 1 & BDCA-3 & - & BDCA-1 & 50,000 \\
\hline
\end{tabular}

FITC = fluorescein isothiocyanate; $\mathrm{PE}=$ phycoerythrin; Per-CP = PeridininChlorophyll-Protein; $\mathrm{APC}=$ allophycocyanin; $\mathrm{TCR}=\mathrm{T}$-cell receptor; $7-\mathrm{AAD}=$ 7-amino-actinomycin-D; BDCA = blood dendritic cell antigen.

\section{Enumeration of $\mathrm{CD} 34^{+}$cells}

CD $34^{+}$HSCs in donor PB, leukapheresis products and manipulated grafts were counted using the ISHAGE protocol [28].

\section{TCR- $\alpha \beta / C D 19$ immunomagnetic depletion}

Leukapheresis collections containing $<60.0 \times 10^{9}$ nucleated cells were washed by centrifugation at $300 \mathrm{~g}$ for 15 minutes with PBS-EDTA-0.5\% human serum albumin (Clini-MACS ${ }^{\circledR}$ washing buffer; Miltenyi Biotec) and were treated with $\gamma$-globulins to minimize the non-specific antibody binding to Fc receptors, before the addition of the biotin-conjugated, anti-TCR- $\alpha \beta$ antibody. Cells were then incubated with magnetic beads conjugated to antibiotin and to anti-CD19 antibodies, were re-suspended at $<300.0 \times 10^{6} / \mathrm{mL}$ and were applied to the fully automated Clini-MACS ${ }^{\circ}$ device [29].

\section{Enumeration of B-cell and T-cell subsets}

The following B-cell subsets were monitored in HSC donors: naïve $\mathrm{B}$ cells $\left(\mathrm{CD} 19^{+} \mathrm{CD} 27^{-} \mathrm{IgD}^{+}\right)$, switched memory $\mathrm{B}$ cells $\left(\mathrm{CD} 19^{+} \mathrm{CD} 27^{+} \mathrm{IgD}{ }^{-}\right)$, non-switched memory $\mathrm{B}$ cells $\left(\mathrm{CD} 19^{+} \mathrm{CD} 27^{+} \mathrm{IgD}^{+}\right)$and double-negative memory $\mathrm{B}$ cells $\left(\mathrm{CD} 19^{+} \mathrm{CD} 27^{-} \mathrm{IgD}^{-}\right)$. [30] Based on $\mathrm{CD} 45 \mathrm{RO}$ and CD62L expression, $\mathrm{T}$ cells were allotted to either of the following subpopulations: naïve $\mathrm{T}$ cells $\left(\mathrm{T}_{\mathrm{N}} ; \mathrm{CD} 45 \mathrm{RO}^{-}\right.$ 
$\mathrm{CD}^{2} \mathrm{~L}^{+}$), effector memory $\mathrm{T}$ cells $\left(\mathrm{T}_{\mathrm{EM}} ; \mathrm{CD} 4 \mathrm{RO}^{+}\right.$ $\left.\mathrm{CD}_{22} \mathrm{~L}^{-}\right)$, central memory $\mathrm{T}$ cells $\left(\mathrm{T}_{\mathrm{CM}} ; \mathrm{CD} 4 \mathrm{RO}^{+}\right.$ CD62 $\mathrm{L}^{+}$) and terminally differentiated effector $\mathrm{T}$ cells $\left(\mathrm{T}_{\mathrm{EFF}} ; \mathrm{CD} 45 \mathrm{RO}^{-} \mathrm{CD}^{-} \mathrm{L}^{-}\right)[31]$.

\section{Enumeration of NK cells}

Three NK-cell subsets were identified and counted. Based on their reciprocal expression of CD16 and CD56, $\mathrm{CD}^{-}$cells within the lymphoid gate were subdivided into fully mature $\mathrm{NK}$ cells $\left(\mathrm{CD} 56^{+} \mathrm{CD} 16^{+}\right)$, tissueresident $\mathrm{NK}$ cells $\left(\mathrm{CD} 56^{+} \mathrm{CD} 16^{-}\right)$and immature $\mathrm{NK}$ cells $\left(\mathrm{CD} 56^{-} \mathrm{CD} 16^{+}\right)$[32].

\section{Enumeration of monocyte and DC subsets}

Three monocyte subsets were analyzed based on CD14 and $\mathrm{CD} 16$ expression: classical $\left(\mathrm{CD} 14^{++} \mathrm{CD} 16^{-}\right)$, intermediate $\left(\mathrm{CD} 14^{++} \mathrm{CD} 16^{+}\right)$and non-classical monocytes $\left(\mathrm{CD} 14^{+} \mathrm{CD} 16^{++}\right)$[9]. Intermediate and non-classical monocytes were collectively referred to as $\mathrm{CD}_{16}{ }^{+}$monocytes. To monitor DC mobilization, cells were stained with the 'Lineage Cocktail-1' and with mAbs directed against CD1c, CD303, CD141, or CD304 [33]. After gating on Lineage ${ }^{-}$events, DCs were enumerated and their frequency was expressed as a percentage of total leukocytes $[9,33]$. 6-sulfo-LacNAc ${ }^{+}$(Slan)-DCs were counted with the anti-M-DC8 antibody recognizing an O-linked carbohydrate modification of P-selectin glycoprotein ligand-1 [34].

\section{Intracellular cytokine staining}

Cytokine production at the single-cell level was assessed with mAbs directed against IFN- $\gamma$, IL-17 and IL-4. CD4 ${ }^{+}$ cells were activated for 4-6 hours with $50 \mathrm{ng} / \mathrm{mL}$ PMA and $1 \mu \mathrm{g} / \mathrm{mL}$ ionomycin, in the presence of inhibitors of protein transport. Following fixation and permeabilization, cells were labeled with cytokine-specific mAbs for 30 minutes at $4^{\circ} \mathrm{C}$ and then analyzed by flow cytometry.

\section{Immunofluorescence analysis}

After staining for surface antigens with mAbs at $4^{\circ} \mathrm{C}$ for 30 minutes, cells were incubated with $0.9 \%$ ammonium chloride for 5 minutes to lyse residual red blood cells. Cells were then extensively washed with PBS - 1\% BSA and were run on a FACS Canto $\mathrm{II}^{\odot}$ flow cytometer (BD Biosciences) with standard equipment. A minimum of 50,000 events was collected and acquired in list mode using the FACS Diva software package (BD Biosciences).

\section{Statistical methods}

The approximation of data distribution to normality was tested preliminarily using statistics for kurtosis and symmetry. Data were presented as median and range, and comparisons were performed with the Mann-Whitney
$U$ test for paired or unpaired data, or with the KruskalWallis test with Bonferroni's correction for multiple comparisons, as appropriate. $P$ values $\leq 0.05$ denoted statistical significance.

\section{Results}

$\mathrm{MZ}$ in adjunct to G-CSF potently mobilizes CD $34^{+} \mathrm{HSCs}$ in healthy donors

We initially enumerated circulating $\mathrm{CD}^{+} 4^{+}$cells in healthy donors receiving G-CSF for 4 consecutive days. Overall, 61 out of 90 donors (68\%) failed to achieve the predefined threshold of $40 \mathrm{CD} 34^{+} \mathrm{HSCs} / \mu \mathrm{L}$ of blood and were operationally defined as 'poor mobilizers' (PM; Figure $1 \mathrm{C}$ and Figure 2). However, 31 out of these 61 donors (51\%) were re-assigned to the 'good mobilizer' (GM) group, since the prediction algorithm favored an apheresis yield $>12 \times 10^{6}$ $\mathrm{CD} 4^{+} \mathrm{HSCs} / \mathrm{kg}$ of recipient's body weight (Figure $1 \mathrm{C}$ ). By contrast, 29 out of the 90 donors (32\%) had postmobilization CD34-cell counts greater than the cutoff value of $40 \mathrm{CD} 34^{+} \mathrm{HSCs} / \mu \mathrm{L}$ on day +4 , and were classified as 'good mobilizers' (GM). Collectively, 60 donors fell into the GM category, whereas the remaining 30 PMs (33\% of the whole donor cohort) received single-dose MZ.

In GMs and PMs, the frequency (Figure 2A) and number (Figure 2B) of circulating $\mathrm{CD}_{3} 4^{+} \mathrm{HSCs}$ were $0.10 \%$ (range 0.02-0.25) and 0.05\% (0.01-0.09; p < 0.0001), and 36.5 cells $/ \mu \mathrm{L}(5-110)$ and 16.0 cells $/ \mu \mathrm{L}(2-36 ; \mathrm{p}<$ $0.0001)$, respectively, on day +4 of G-CSF administration. Figure $2 \mathrm{~B}$ also illustrates that $\mathrm{CD} 34^{+}$-cell counts further increased on day +5 in GMs given G-CSF alone, when compared with those recorded on day +4 . PMs consistently achieved $>40 \mathrm{CD} 34^{+}$cells $/ \mu \mathrm{L}$ of blood after single-dose $\mathrm{MZ}$, and their $\mathrm{CD} 4^{+}$counts on day +5 were even higher when compared with those measured in GMs given G-CSF alone $[135.0$ cells $/ \mu \mathrm{L}(40-277)$ vs. 99.0 cells $/ \mu \mathrm{L}$ (29-232); $\mathrm{p}=0.0089]$. Interestingly, PMs given single-dose MZ had higher day-5 monocyte and lymphocyte counts compared with GMs receiving G-CSF alone (Figure $2 \mathrm{C}-\mathrm{D}$ ). The role of $\mathrm{MZ}$ in mobilizing monocytes and lymphocytes was further reinforced by the observation that PMs and GMs had similar monocyte and lymphocyte counts on day +4 , before receiving single-dose MZ (Figure 2C-D).

As expected, larger numbers of CD $34^{+}$HSCs were collected, with one single apheresis session, after mobilization with G-CSF + MZ compared with G-CSF alone (Table 2). However, children whose HSC donors were given MZ had a significantly greater body weight compared with children transplanted with G-CSF-mobilized HSC products [45.0 kg (18-74) vs. $20.5 \mathrm{~kg}(4-66) ; \mathrm{p}<0.0001]$.

\section{Effects of $M Z$ on circulating immune cells}

It is presently unknown whether single-dose $\mathrm{MZ}$ affects T-cell and B-cell phenotype in G-CSF-treated healthy 


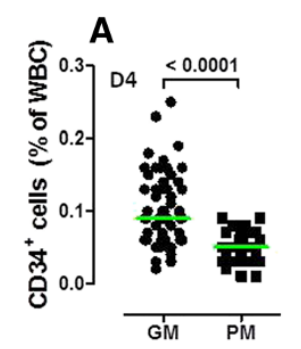

c

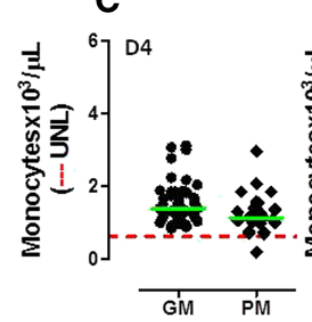

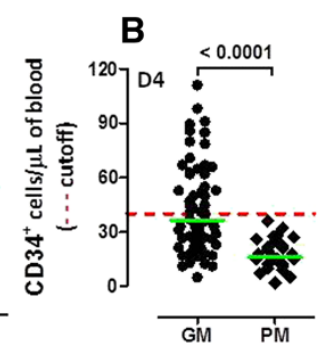

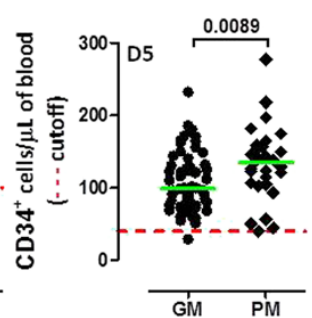

D
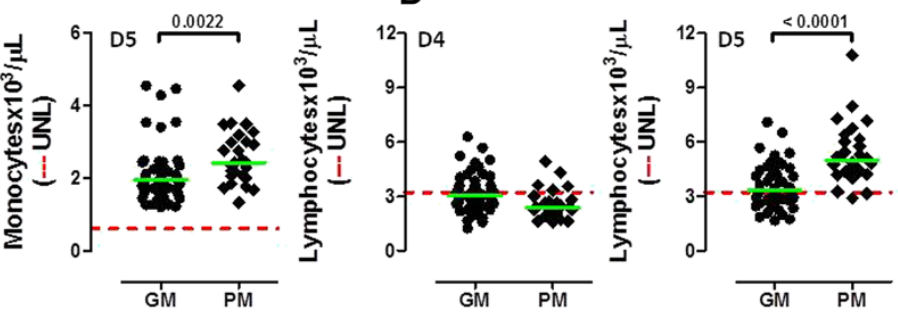

Figure $2 \mathrm{CD}^{+} 4^{+}$HSC, monocyte and lymphocyte mobilization with G-CSF and plerixafor (MZ). Relative frequency (panel A) and absolute number (panel B) of CD34 $4^{+}$SSC, as well as absolute monocyte (panel C) and lymphocyte counts (panel D), are shown in 'good mobilizers' (GMs) and 'poor mobilizers' (PMs) on day +4 (left graph) and day +5 (right graph). The green bar denotes the median value. Comparisons were performed with the Mann-Whitney $U$ test for paired data. The dotted red line in panel $\mathbf{B}$ refers to the predefined cutoff of $40 \mathrm{CD} 34^{+} \mathrm{HSCS} / \mu \mathrm{L}$ of blood used on day +4 to discriminate the PMs from the GMs. The dotted red line in panels $\mathbf{C}$ and $\mathbf{D}$ indicates the upper normal limit (UNL) of monocyte and lymphocyte count. WBC = white blood cells.

subjects $[17,18]$. We thus extensively characterized PB samples from donors receiving either G-CSF alone or G-CSF and MZ. No statistically significant differences in the relative proportion of TCR- $\alpha \beta$ and TCR- $\gamma \delta$ expressing $\mathrm{CD}^{+}{ }^{+} \mathrm{T}$ cells were detected, when comparing baseline [94.0\% (88.8-98.8) and 5.4\% (1.0-9.1), respectively] and post-mobilization samples [95.6\% (86.5-99.3) and 4.0\% (0.6-12.7), respectively], irrespective of the mobilization protocol (Additional file 1). Moreover, the frequency of $T_{N}$, $\mathrm{T}_{\mathrm{CM}}, \mathrm{T}_{\mathrm{EM}}$ and terminally differentiated effectors was comparable in baseline and post-mobilization samples. Specifically, $\mathrm{T}_{\mathrm{N}}$ cells accounted for $29.7 \%(2.4-62.2)$ and $30.9 \%$ (1.0-58.7), and for $32.2 \%(2.4-56.4)$ and $26.6 \%(2.0-53.4)$ of the $\mathrm{CD}^{+}$and $\mathrm{CD} 8^{+} \mathrm{T}$ cells before and after treatment with G-CSF (Additional file 1), indicating that

Table 2 Number of CD34 ${ }^{+}$HSCs harvested and infused according to the mobilization regimen

\begin{tabular}{|c|c|c|c|}
\hline & \multicolumn{3}{|c|}{$\mathrm{CD}^{+} 4^{+} \mathrm{HSC}$ yield } \\
\hline & G-CSF alone & $\mathrm{G}-\mathrm{CSF}+\mathrm{MZ}$ & $P$ value \\
\hline \multicolumn{4}{|c|}{ Harvested CD34+ HSCs } \\
\hline Median & $462.6 \times 10^{6}$ & $655.9 \times 10^{6}$ & 0.0008 \\
\hline Range & $93.2-1,216$ & $176.5-1,284$ & \\
\hline \multicolumn{4}{|c|}{ Infused CD34 ${ }^{+} \mathrm{HSCS}$} \\
\hline Median & $19.83 \times 10^{6} / \mathrm{kg}$ & $16.83 \times 10^{6} / \mathrm{kg}$ & 0.0044 \\
\hline Range & $7.5-79.0$ & $5.8-29.21$ & \\
\hline
\end{tabular}

$\mathrm{MZ}=$ plerixafor (Mozobil $)$; HSC = hematopoietic stem cells. Comparisons between groups were performed with the Mann-Whitney $U$ test for unpaired determinations.
G-CSF administration had no apparent effect on the re-circulation of individual T-cell subsets. We also quantitated B-cell subpopulations in mobilized donors. Again, no appreciable differences were detected in the frequency of naïve B cells, double-negative B cells, switched memory $B$ cells and non-switched memory B cells (Additional file 2). Furthermore, the addition of MZ to the G-CSFbased mobilization regimen exerted no measurable effect on the relative frequency of $\mathrm{T}$-cell and B-cell subsets (data not shown). Previous studies showed that G-CSF skews Tcell function towards a regulatory profile, both in mice and in humans $[15,17]$. We thus measured the frequency of $\mathrm{CD} 4^{+} \mathrm{T}$ cells expressing intracellular IFN- $\gamma, \mathrm{IL}-17$ and IL-4 at baseline and after mobilization with G-CSF. Figure $3 \mathrm{~A}-\mathrm{B}$ illustrates that the frequency of IFN- $\gamma-$ expressing $\mathrm{CD} 4^{+} \mathrm{T}$ cells was significantly lower in mobilized PB samples compared with baseline. By contrast, IL-4- and IL-17-producing T cells were unchanged. Intriguingly, no differences were found in the frequency of IFN- $\gamma$-expressing $\mathrm{CD}^{+} \mathrm{T}$ cells (Figure $3 \mathrm{C}$ ). When data were dichotomized based on the mobilization regimen used, no statistically significant differences were detected in the frequency of $\mathrm{CD}^{+}$and $\mathrm{CD}^{+} \mathrm{T}$ cells expressing intracellular IFN- $\gamma$ (Figure 3D).

As shown in Figure 4A-B, the overall frequency of $\mathrm{PB}$ NK cells was significantly lower after HSC mobilization compared with baseline. This reduction was mainly accounted for by the subgroup of PMs who were given MZ (Figure 4B). Notably, both fully mature $\mathrm{CD} 56^{+} \mathrm{CD} 16^{+} \mathrm{NK}$ cells and tissue-resident $\mathrm{CD} 56^{+} \mathrm{CD} 16^{-} \mathrm{NK}$ cells were 


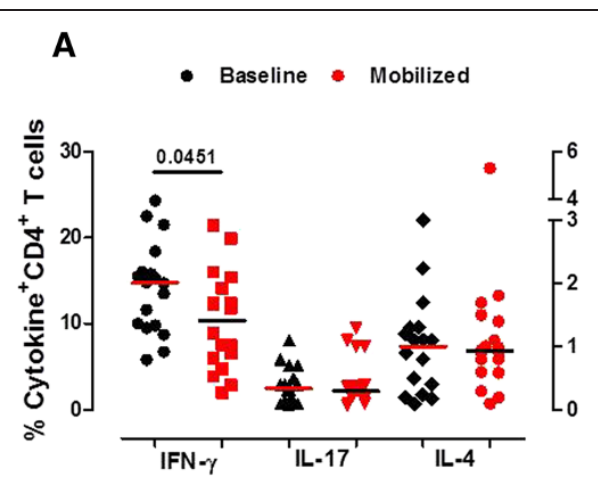

C

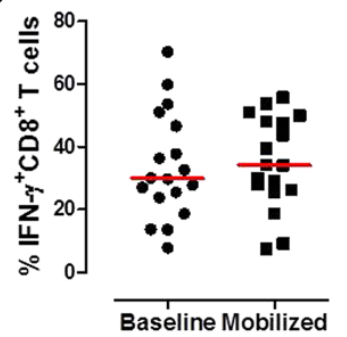

B

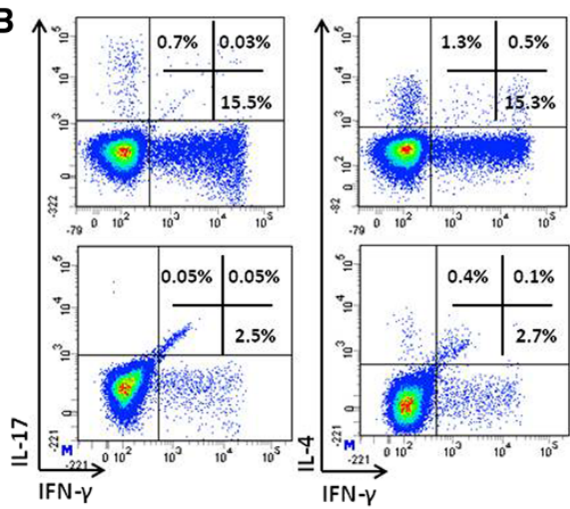

D

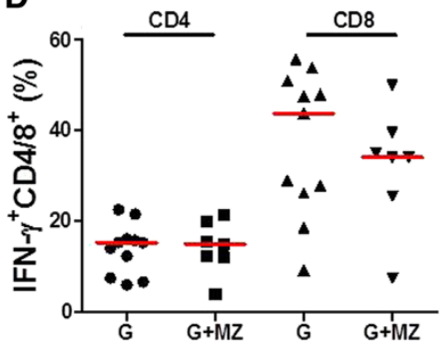

Figure 3 T-cell cytokine secretion profile after mobilization with G-CSF and plerixafor (MZ). PBMCs from 18 randomly selected donors given G-CSF alone ( $G ; n=11)$ or G-CSF and plerixafor $(M Z ; n=7)$ were stimulated with polyclonal activators in vitro and then fixed, permeabilized and stained with anti-IFN- $/ / \mathrm{LL}-17 / \mathrm{LL}-4 \mathrm{mAbs}$. Panel $\mathbf{A}$ : Percentage of cytokine-expressing CD4 ${ }^{+} \mathrm{T}$ cells at baseline and after mobilization. Bars denote the median value. Comparisons were performed with the Mann-Whitney $U$ test for paired determinations. Panel B: A representative experiment for the enumeration of Th1, Th17 and Th2 CD4 ${ }^{+}$T cells is shown. The percentage of cells staining positively for each cytokine is indicated. Markers were set according to the proper isotypic control (not shown). Panel C: Percentage of IFN- - -expressing CD $8^{+}$T cells at baseline and after mobilization. Bars denote the median value. Panel $\mathbf{D}$ : Percentage of IFN- $\gamma$-expressing $\mathrm{CD}^{+}$and $\mathrm{CD} 8^{+} \mathrm{T}$ cells in healthy donors assigned to the GM (G-CSF alone) and to the PM group (G-CSF + MZ). Bars denote the median value. Differences were not statistically significant.

significantly lower after G-CSF administration, whereas immature $\mathrm{CD}^{-} 6^{-} \mathrm{CD} 16^{+} \mathrm{NK}$ cells were not affected by the HSC mobilization regimen (Figure 4C). Mirroring the above data on NK cells, the frequency of NK-like CD56 ${ }^{+}$ $\mathrm{T}$ cells was also reduced after G-CSF mobilization, especially in PMs given single-dose MZ (Figure 4D). Collectively, these experiments suggest that NK cells and NK-like T cells may be less represented in healthy donors given GCSF-based mobilization and that this phenomenon is accentuated by the co-administration of MZ.

We then aimed at enumerating monocyte and DC subsets in mobilized donors. Classical, intermediate and non-conventional monocytes were labeled and quantitated as shown in Figure 4E. Although the frequency of conventional $\mathrm{CD} 14^{+} \mathrm{CD} 16^{-}$monocytes was not significantly different in baseline compared with post-mobilization samples, the proportion of $\mathrm{CD} 16^{+}$monocytes increased after G-CSF administration, both in the GM and in the PM group (Figure 4F-G). Slan-DCs (Figure 5A) were not appreciably mobilized into PB by treatment with G-CSF, either alone or combined with MZ (data not shown). Because G-CSF induces CXCR4 cleavage and disrupts the CXCR4/SDF- $1 \alpha$ interaction during HSC mobilization,
[35] we reasoned that a differential regulation of CXCR4 expression on the surface of Slan-DCs could account for low-level Slan-DC mobilization after combined treatment with G-CSF and MZ. As depicted in Figure 5B, CXCR4 expression significantly decreased on monocytes from donors given G-CSF, after labeling with CD184-12G5 antibodies. Comparable reductions were measured on other leukocyte subsets, such as lymphocytes and neutrophils (data not shown). By contrast, CXCR4 was not apparently down-regulated on circulating Slan-DCs, irrespective of the mobilization regimen (Figure 5C).

Finally, no changes were recorded in the frequency of MDC1, MDC2 or plasmacytoid CD $303^{+}$or $\mathrm{CD} 34^{+}$DCs when comparing baseline and post-mobilization samples, irrespective of the mobilization regimen (Additional file 3) and in keeping with previous reports showing no changes in the frequency of BDCA-2 $2^{+}$DCs in donors given G-CSF [36]. Collectively, these experiments suggest that single-dose MZ exerts no major effects on circulating B-cell and T-cell subsets and on monocyte/ DC subpopulations, although it may reduce the frequency of blood NK cells and NK-like T cells, when compared with G-CSF alone. 

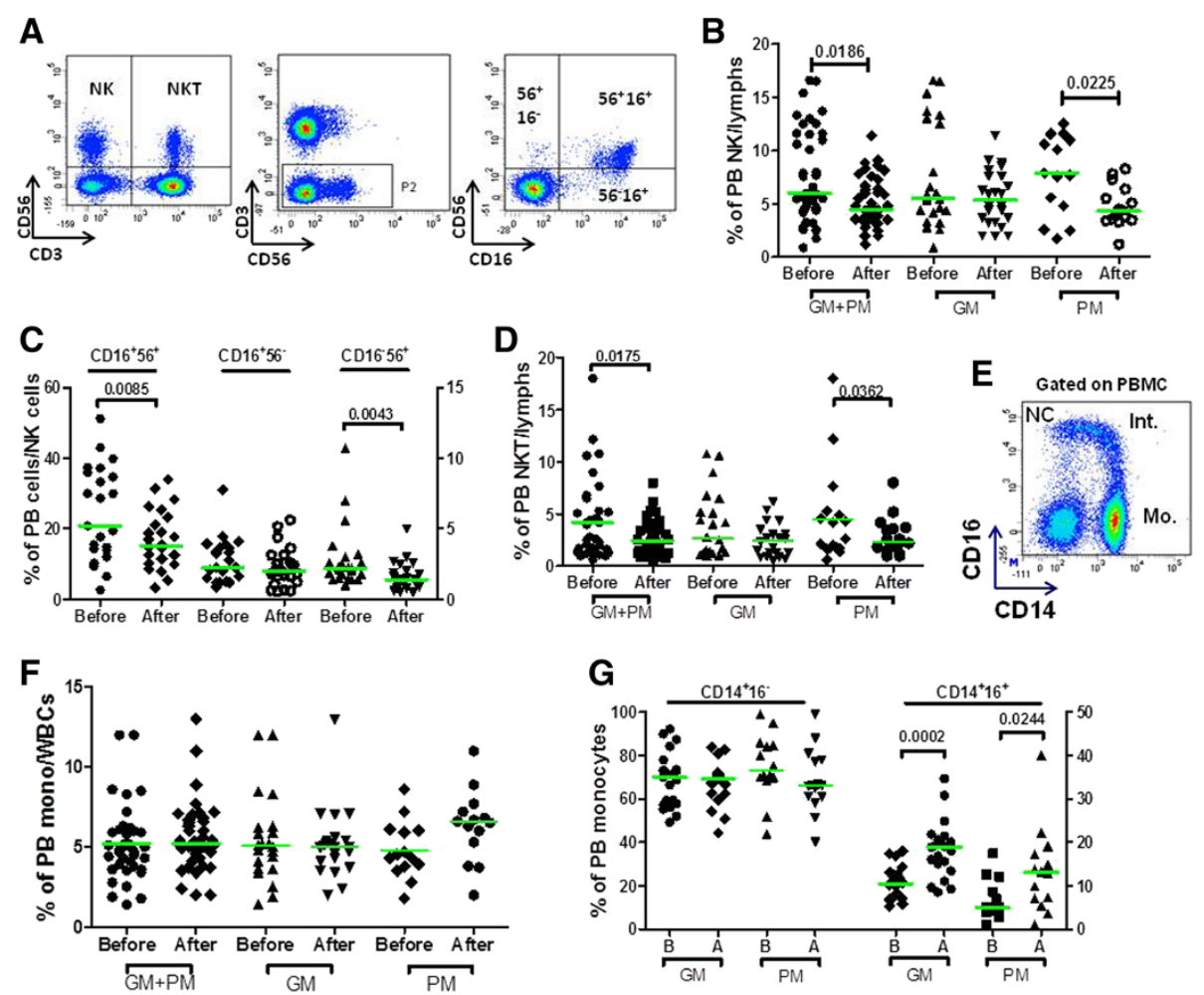

Figure 4 Mobilization of NK cells, NK-like T cells and monocytes with G-CSF and plerixafor (MZ). Panel A: Donor PBMCs were labeled with mAbs directed against CD3, CD16 and CD56 to enumerate classical NK cells, NK-cell subsets and NK-like T cells. A representative experiment illustrating the gating strategy for the analysis of NK cells and NK-like T cells is shown. After gating on CD3- events (P2), dot plots were used to visualize the reciprocal expression of CD16 and CD56 on NK-cell subsets. Panel B: The percentage of NK cells within the lymphoid gate (lymphs) is plotted. PB samples from 40 randomly selected donors were used for this analysis. GM = 'good mobilizers'; PM = 'poor mobilizers'; before = baseline samples; after = samples collected after HSC mobilization. Bars indicate the median value. Comparisons were performed with the Mann Whitney $U$ test for paired determinations. Panel C: The percentage of each subset/total NK cells is plotted on y axes. Bars indicate the median value. Comparisons were performed with the Mann Whitney $U$ test for paired determinations. Before = baseline samples; after = samples collected after HSC mobilization. Panel D: Percentage of NK-like T cells within the lymphoid gate. Bars indicate the median value. Comparisons were performed with the Mann Whitney $U$ test for paired determinations. Panel E: Strategy to enumerate monocyte subsets in donors' PB. Cells with a CD $14^{++} \mathrm{CD} 16$ phenotype were considered to be conventional monocytes (Mo.); conversely, cells with a CD $14^{+} \mathrm{CD} 16^{+}$(intermediate monocytes, Int.) or a CD $14^{+} \mathrm{CD} 16^{++}$phenotype (non-conventional monocytes, NC) were referred to as $\mathrm{CD} 16^{+}$monocytes $[9,55]$. No statistically significant differences emerged when comparing the frequency of monocytes before and after G-CSF \pm MZ (panel F). WBC = white blood cells. The frequency of CD $14^{+} \mathrm{CD} 16^{-}$and $\mathrm{CD} 14^{+} \mathrm{CD} 16^{+}$monocytes before and after HSC mobilization is depicted in panel G. Bars indicate median values. Comparisons were performed with the Mann-Whitney $U$ test for paired determinations.

\section{Effects of $M Z$ on graft composition}

In 70 randomly selected HSC donors (43 GMs given G-CSF only and 27 PMs receiving G-CSF plus MZ) undergoing a standard large-volume (15-20 L) leukapheresis, the graft was extensively characterized in terms of immune effector cells with particular relevance to the setting of haploidentical HSCT, such as NK cells, $\mathrm{CD}^{+}$ CD56 ${ }^{+}$NK-like T cells, monocytes and DCs. [37-39] For the purpose of comparison, we also enumerated immune effectors in $10 \mathrm{BM}$ samples from healthy HLAidentical sibling donors. TCR- $\alpha \beta / C D 19-$ depleted grafts obtained after either mobilization regimen were highly enriched with NK cells compared with normal BM samples (Figure 5D). However, the frequency and absolute numbers of NK cells were comparable in grafts collected after the administration of either G-CSF alone or G-CSF and MZ (Figure 5D-E). Although grafts from donors assigned to the GM group had a higher frequency of NKlike $\mathrm{CD} 6^{+} \mathrm{T}$ cells compared with those from the PM group (Figure 5F), the overall number of CD56 ${ }^{+} \mathrm{NK}$-like $\mathrm{T}$ cells harvested was similar (Figure 5G).

Both conventional and $\mathrm{CD} 16^{+}$monocytes were contained at higher frequency in TCR- $\alpha \beta / C D 19$-depleted grafts, compared with normal BM samples (Figure 6A-B). As shown in Figure $6 \mathrm{C}-\mathrm{D}$, both monocyte populations were more abundant in G-CSF + MZ-mobilized grafts compared with grafts collected after G-CSF alone. 6-sulfo$\mathrm{LacNAc}^{+}$(Slan) DCs constitute $0.5-2 \%$ of all PBMCs, are $\mathrm{CD} 14^{\text {low }} \mathrm{CD} 16^{+}$and are a highly phagocytic monocyte subset inducing potent pro-inflammatory Th1 and Th17 

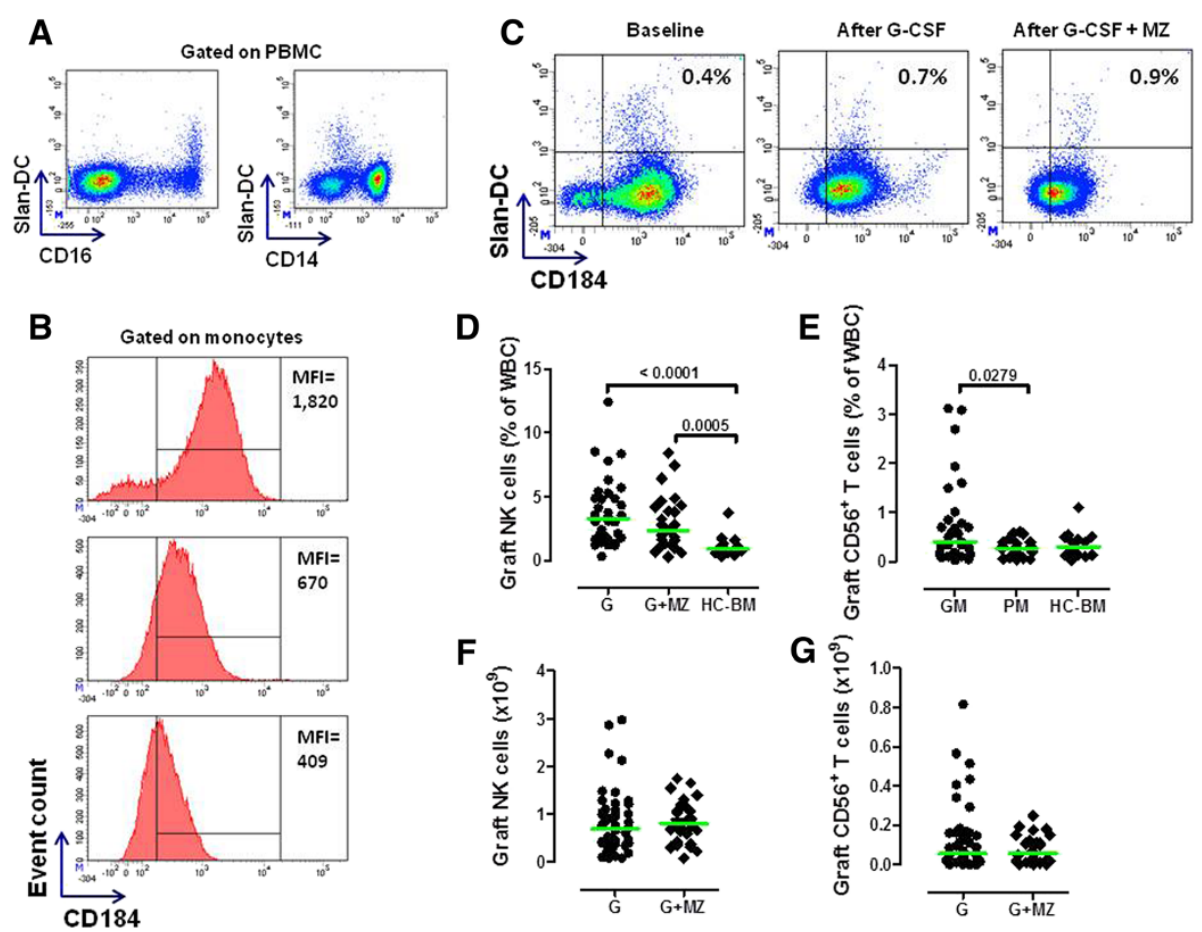

Figure 5 Expression of CXCR4 (CD184) on Slan-DCs and numbers of NK cells and NK-like T cells in HSC grafts collected after mobilization with G-CSF and plerixafor (MZ). Panel $\mathbf{A}$ shows the results of a representative experiment aimed at enumerating 6-sulfo-LacNAC ${ }^{+}$ (Slan)-DCs in donors' PB. Slan-DCs were consistently CD16 ${ }^{+}$and expressed low-level CD14. Panels B and C: PB samples from PMs given G-CSF and single-dose MZ were double-stained with anti-CD184 and anti-M-DC8 mAbs to quantitate CXCR4 expression on Slan-DCs. The Mean Fluorescence Intensity (MFI) of CD184 expression on peripheral CD14 ${ }^{+}$monocytes is shown in a representative experiment out of 4 with similar results. The marker was set according to the proper isotypic control. Panel C shows preserved levels of CD184 on Slan-DCs after HSC mobilization with G-CSF and MZ. This is in contrast with the marked down-regulation of CD184 on monocytes that is depicted in panel $\mathbf{B}$. One representative experiment out of 4 with similar results is shown. Markers were set according to proper isotypic controls. Panels D-G: Frequency and absolute numbers of NK cells and NK-like T cells in TCR-aß/CD19-depleted haploidentical grafts. After the immunomagnetic removal of TCR- $a \beta^{+} T$ cells and CD19 ${ }^{+}$B cells, mononuclear cells contained within the graft were extensively characterized using mAbs directed against CD3, CD16 and CD56 with the aim at identifying NK cells and NK-like T cells. NK cells and NK-like T cells were also quantitated in aliquots of 10 normal BM samples collected under general anesthesia and intended for HLA-identical sibling HSCT. Comparisons among data sets were performed with the Mann Whitney $U$ test for unpaired determinations or with the analysis of variance (ANOVA), as appropriate. $\mathrm{HC}=$ healthy control; WBC = white blood cells.

responses [40]. As illustrated by Figure 6E- F, the frequency of Slan-DCs was significantly lower in grafts mobilized with G-CSF + MZ $(0.85 \%$ of total leukocytes, 0.06-1.3) compared with G-CSF alone (1.4\%, 0.5-4.15; $\mathrm{p}=$ 0.0045), although this did not translate into the collection of lower numbers of Slan-DCs.

Finally, Figure 7 shows that both MDC2 and plasmacytoid DCs were significantly more represented in grafts collected after mobilization with G-CSF and MZ. Thus, the number of MDC1, MDC2 and plasmacytoid DCs collected from donors given G-CSF and MZ was significantly greater. Also, the frequency of DC subsets was higher in TCR- $\alpha \beta / C D 19$-depleted grafts compared with normal BM samples (Figure 7). Table 3 summarizes the absolute numbers of cells infused in children receiving the TCR- $\alpha \beta / C D 19-$ depleted haploidentical grafts collected after G-CSF alone or G-CSF + MZ. Whereas the number of monocytes and DCs infused in the two patient groups was similar, children given G-CSF-mobilized grafts received significantly greater numbers of NK cells and NK-like T cells, as well as pro-inflammatory Slan-DCs, compared with children given HSCT from donors mobilized with G-CSF + MZ (Table 3). These differences can be accounted for by the significantly higher number of nucleated cells collected from GMs treated with G-CSF alone (Table 3). Also, the fact that children receiving haploidentical HSCT from GMs had a lower body weight may have translated into the infusion of higher numbers of NK cells, NKT cells and Slan-DCs.

From a clinical standpoint, neither the HSC mobilization regimen (G-CSF alone vs. G-CSF and MZ) nor the number of monocytes and DCs infused correlated with either the occurrence of acute GVHD or the reactivation of viral infections (data not shown). By contrast, patients who developed chronic GVHD had received lower numbers of conventional $\mathrm{CD} 14^{+} \mathrm{CD} 16^{-}$monocytes 

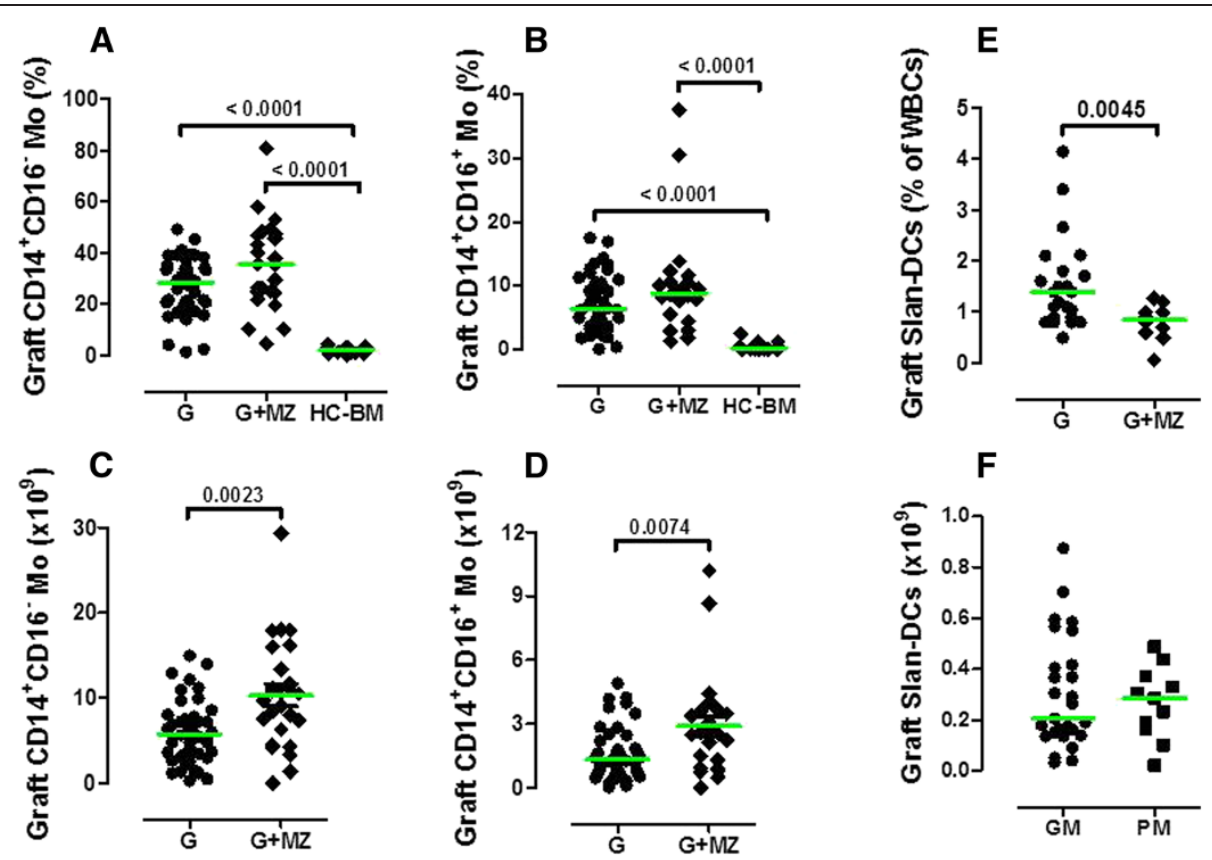

Figure 6 Numbers of monocytes and Slan-DCs in HSC grafts collected after mobilization with G-CSF and plerixafor (MZ). After the immunomagnetic removal of TCR-a $\beta^{+} T$ cells and $C D 19^{+}$B cells, mononuclear cells contained within the graft were extensively characterized using mAb directed against surface antigens known to be expressed on monocytes and on pro-inflammatory Slan-DCs. Monocytes and Slan-DCs were also quantitated in normal BM samples from matched-sibling donors. The frequency and absolute numbers of CD $14^{+} \mathrm{CD} 16^{-}$and $C D 14^{+} \mathrm{CD} 16^{+}$ monocytes in TCR-aß/CD19-depleted haploidentical grafts are depicted in panels $\mathbf{A}-\mathbf{D}$. The frequency and absolute number of Slan-DCs are shown in panels E-F. The green bars indicate median values. $G M=$ 'good mobilizers'; PM = 'poor mobilizers'; HC = healthy control. Comparisons among data sets were performed with the Mann Whitney $U$ test for unpaired determinations or with the analysis of variance (ANOVA), as appropriate.
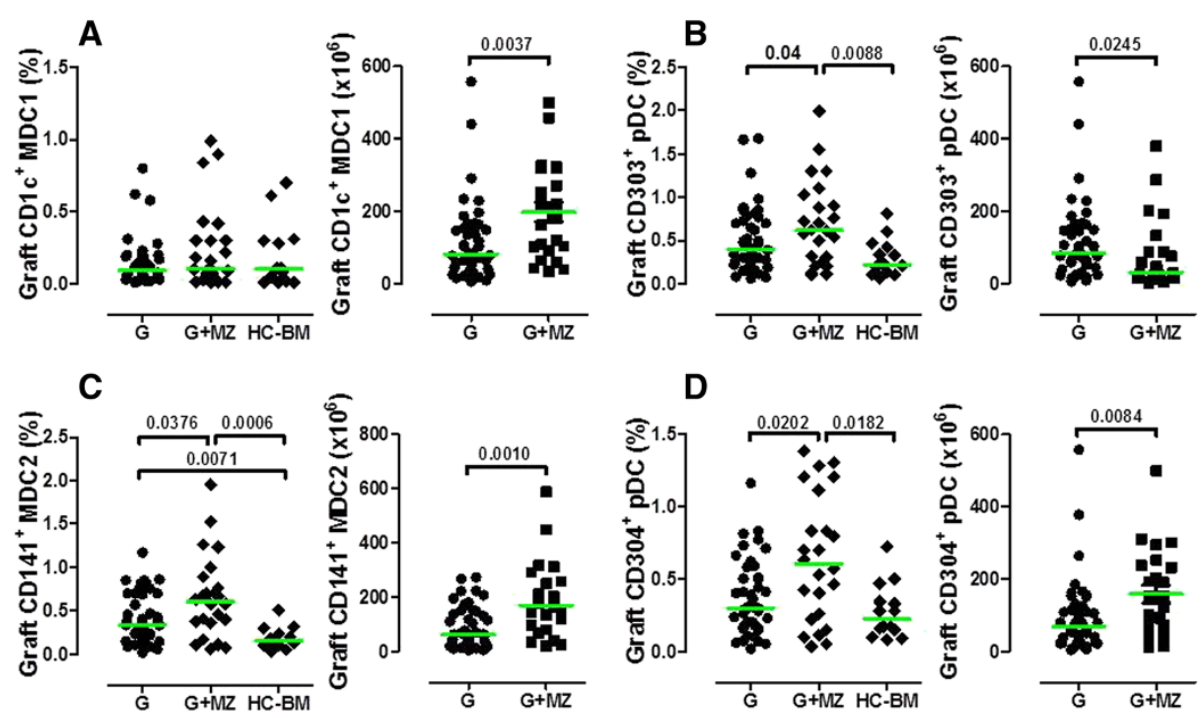

Figure 7 Numbers of myeloid and plasmacytoid DCs in HSC grafts collected after mobilization with G-CSF and plerixafor (MZ). After the immunomagnetic removal of TCR- $a \beta^{+} T$ cells and $C D 19^{+} B$ cells, mononuclear cells contained within the graft were extensively characterized using mAbs directed against surface antigens selectively expressed on DC subpopulations [33]. DC subsets were also quantitated in aliquots of 10 normal BM samples from matched-sibling donors. Panels $\mathbf{A}$ and $\mathbf{B}$ depict the frequency and number of MDC1 and plasmacytoid CD303 ${ }^{+}$DCs, respectively, whereas panels $\mathbf{C}$ and $\mathbf{D}$ show the frequency and number of MDC2 and CD304 ${ }^{+}$plasmacytoid DCs, respectively. Comparisons among data sets were performed with the Mann Whitney $U$ test for unpaired determinations or with the analysis of variance (ANOVA), as appropriate. 
Table 3 Number of nucleated cells, NK cells, monocytes and DCs infused (per $\mathrm{kg}$ of recipient's body weight) according to the mobilization regimen

\begin{tabular}{|c|c|c|c|}
\hline & G-CSF alone & $\mathrm{G}-\mathrm{CSF}+\mathrm{MZ}$ & $P$ value \\
\hline \multicolumn{4}{|l|}{ Total NC } \\
\hline Median & $1.17 \times 10^{9} / \mathrm{kg}$ & $0.71 \times 10^{9} / \mathrm{kg}$ & 0.0002 \\
\hline Range & $0.33-2.99$ & $0.28-1.6$ & \\
\hline \multicolumn{4}{|l|}{ NK cells } \\
\hline Median & $31.3 \times 10^{6} / \mathrm{kg}$ & $16.8 \times 10^{6} / \mathrm{kg}$ & 0.0016 \\
\hline Range & $1.8-176.8$ & $2.8-55.9$ & \\
\hline \multicolumn{4}{|c|}{ NK-like T cells } \\
\hline Median & $3.64 \times 10^{6} / \mathrm{kg}$ & $1.56 \times 10^{6} / \mathrm{kg}$ & 0.0016 \\
\hline Range & $0.4-34.8$ & $0.2-6.64$ & \\
\hline \multicolumn{4}{|c|}{ CD16 monocytes } \\
\hline Median & $312.2 \times 10^{6} / \mathrm{kg}$ & $226.8 \times 10^{6} / \mathrm{kg}$ & 0.34 \\
\hline Range & $15.9-729.8$ & $28.5-667.0$ & \\
\hline \multicolumn{4}{|c|}{$\mathrm{CD} 16^{+}$monocytes } \\
\hline Median & $74.9 \times 10^{6} / \mathrm{kg}$ & $63.6 \times 10^{6} / \mathrm{kg}$ & 0.46 \\
\hline Range & $1.5-231.7$ & 8.3-169.6 & \\
\hline \multicolumn{4}{|l|}{ Slan-DCs } \\
\hline Median & $1.40 \times 10^{6} / \mathrm{kg}$ & $0.85 \times 10^{6} / \mathrm{kg}$ & 0.0008 \\
\hline Range & $0.5-4.14$ & $0.06-1.27$ & \\
\hline \multicolumn{4}{|c|}{$\mathrm{CD}_{1} \mathrm{C}^{+} \mathrm{MDC} 1$} \\
\hline Median & $0.84 \times 10^{6} / \mathrm{kg}$ & $0.88 \times 10^{6} / \mathrm{kg}$ & 0.88 \\
\hline Range & $0.1-13.1$ & $0.04-9.66$ & \\
\hline \multicolumn{4}{|c|}{$\mathrm{CD} 03^{+} \mathrm{pDCs}$} \\
\hline Median & $4.12 \times 10^{6} / \mathrm{kg}$ & $4.73 \times 10^{6} / \mathrm{kg}$ & 0.82 \\
\hline Range & $0.72-13.66$ & $0.61-22.9$ & \\
\hline \multicolumn{4}{|c|}{$\mathrm{CD}_{141^{+} \mathrm{MDC} 2}$} \\
\hline Median & $3.74 \times 10^{6} / \mathrm{kg}$ & $4.15 \times 10^{6} / \mathrm{kg}$ & 0.55 \\
\hline Range & $0.36-14.5$ & $0.33-22.4$ & \\
\hline \multicolumn{4}{|c|}{$\mathrm{CD} 34^{+} \mathrm{pDCs}$} \\
\hline Median & $3.8 \times 10^{6} / \mathrm{kg}$ & $3.1 \times 10^{6} / \mathrm{kg}$ & 0.78 \\
\hline Range & $0.2-13.0$ & $0.2-14.7$ & \\
\hline
\end{tabular}

$\mathrm{NC}=$ nucleated cells; $\mathrm{MZ}=$ plerixafor $\left.(\text { Mozobil })^{\circ}\right) ; \mathrm{MDC} 1$ = type 1 myeloid $\mathrm{DC}$; MDC2 = type 2 myeloid DCs. Comparisons between groups were performed with the Mann-Whitney $U$ test for unpaired determinations.

$\left(3.76 \times 10^{6} / \mathrm{kg}, 1.7-10.1\right)$ compared with children without chronic GVHD $\left(11.45 \times 10^{6} / \mathrm{kg}, 0.6-144.2 ; \mathrm{p}=0.016\right]$.

\section{Discussion}

Herein, we show that the addition of 'immediate salvage' MZ to a standard, G-CSF-based mobilization regimen augments HSC yield in HLA-haploidentical donors showing less-than-optimal CD34-cell mobilization, and that MZ administration affects the graft cell composition. Thirty-two percent of our donors were operationally defined as PMs and were given MZ to increase HSC mobilization. More than $95 \%$ of the donors collected the required mega-dose of HSCs with a single apheresis session.

Currently, anecdotal reports describe the 'just-in-time' application of MZ to healthy donors, either as single agent or after mobilization failure with G-CSF [22-24]. In our donor cohort, single-dose $\mathrm{MZ}$ given on day +5 increased the count of CD34 ${ }^{+}$HSCs by 8.2-fold (range 1.4-29.2), compared with that measured after 4 days of G-CSF treatment. This is remarkably similar to the 8fold increase of $\mathrm{CD}_{3} 4^{+}$HSCs reported in donors given MZ only [23].

The few available data on immunological effects of $\mathrm{MZ}$ are mostly limited to cancer patients and show that $\mathrm{CD}^{+}{ }^{+} \mathrm{T}$-cell release of IFN- $\gamma$ and TNF- $\alpha$ may be higher in autologous grafts collected after G-CSF and MZ, compared with G-CSF alone [25]. We previously showed that G-CSF polarizes human T-cell and DC function towards a tolerogenic profile, implying that G-CSFmobilized cell therapy products may be intrinsically less capable of inducing uncontrollable GVHD [17,19,41]. This is reinforced by intriguing observations in major histocompatibility complex (MHC)-matched HSCT, where mice given G-CSF-mobilized splenocytes experienced lower rates of skin GVHD compared with recipients of MZ-mobilized splenocytes [42]. In our healthy donors treated with G-CSF, the down-regulation of $\mathrm{CD}_{4}^{+}$ T-cell production of IFN- $\gamma$ was not potentiated by singledose MZ. Furthermore, IL-17 and IL- 4 release by $\mathrm{CD}^{+} \mathrm{T}$ cells were not affected by G-CSF and/or MZ administration. These observations are in line with pre-clinical data showing that MZ alone, in contrast to G-CSF, is unable to alter the phenotype and cytokine polarization of $\mathrm{T}$ cells, as well as T-cell's ability to induce acute GVHD [43]. It must be emphasized that, in our study, neither G-CSF nor MZ significantly impaired IFN- $\gamma$ production by $\mathrm{CD}^{+} \mathrm{T}$ cells. Notably, studies in mice suggest that G-CSF may separate GVHD and graft-versus-leukemia (GVL) responses by exerting suppressive effects on $\mathrm{CD}_{4}{ }^{+} \mathrm{T}$ cells, that are implicated in GVHD, while preserving the cytolytic pathways of $\mathrm{CD}^{+} \mathrm{T}$ cells that are critical for effective GVL [44]. At variance with a recent report on the immunological effects of single-dose MZ in healthy donors [42], we were unable to detect any difference in the frequency of naïve B cells after MZ administration. Conceivably, any MZ effect on the recirculation of B-cell subsets may have been obscured by treatment with G-CSF during the 4 days preceding MZ administration. However, neither that study [42] nor our own report identified any modification of CD4 and CD8 T-cell frequencies that could be directly attributable to $\mathrm{MZ}$.

In our cohort of 90 donors, HSC mobilization with G-CSF translated into lowered frequencies of both NK cells and NK-like CD56 ${ }^{+} \mathrm{T}$ cells, a phenomenon that 
was mainly accounted for by a reduction of fully mature $\mathrm{CD}_{56}{ }^{+} \mathrm{CD} 16^{+}$and tissue-resident $\mathrm{CD} 56^{+} \mathrm{CD} 16^{-} \mathrm{NK}$ cells, with preserved frequencies of immature $\mathrm{CD} 56^{-} \mathrm{CD} 16^{+}$ NK cells. Interestingly, the frequency of both NK cells and NK-like CD56 ${ }^{+} \mathrm{T}$ cells was reduced in the PM group receiving single-dose MZ. Although the number of NK cells collected was not significantly different when comparing donors given G-CSF alone with those receiving G-CSF in combination with MZ, higher numbers of both NK cells and NK-like $\mathrm{CD}^{+} 6^{+} \mathrm{T}$ cells were infused in children transplanted with G-CSF-mobilized HSC products. A potential clinical implication of this finding pertains to the field of graft engineering, insofar donor mobilization with G-CSF alone might offer an advantage over the use of G-CSF + MZ for patients with NK-susceptible hematological malignancies [37].

As previously published, G-CSF-mobilized monocytes are functionally defective [45]. In our study, treatment with G-CSF and MZ potently mobilized donor monocytes, especially the $\mathrm{CD} 16^{+}$subset of intermediate/nonconventional monocytes. Although the frequency of both conventional and $\mathrm{CD} 16^{+}$monocytes was higher in TCR$\alpha \beta / C D 19-$ depleted HSC grafts compared with normal BM samples, the overall number of conventional and $\mathrm{CD}^{+} 6^{+}$ monocytes infused in our haploidentical HSCT recipients was not correlated with the mobilization regimen used in the donor. It has been demonstrated that macrophages generated from $\mathrm{CD}_{16}{ }^{+}$monocytes manifest higher phagocytic activity compared with macrophages derived from classical monocytes [46]. In addition, $\mathrm{CD} 14^{\mathrm{dim}} \mathrm{CD} 16^{+}$ monocytes are endowed with a unique patrolling function, as they detect virally infected and damaged cells and produce pro-inflammatory cytokines [47]. In light of these findings, it is conceivable that $\mathrm{CD} 16^{+}$monocytes infused with the TCR- $\alpha \beta / C D 19-$ depleted haploidentical grafts may protect the recipient from infectious episodes, while contributing to prevention of GVHD [48].

There is also evidence that G-CSF mobilizes IL-12/ TNF- $\alpha$-producing, pro-inflammatory Slan-DCs [49]. Thus, Slan-DCs may incite GVHD on the one side, while preserving GVL reactivity on the other side. In our study, the addition of MZ to G-CSF did not affect the mobilization of Slan-DCs. In addition, the frequency of Slan-DCs was lower in HSC grafts collected after the combined treatment with G-CSF and MZ. Because G-CSF administration is associated with in vivo cleavage of the N-terminus of CXCR4 on BM-resident HSCs [35], it is tempting to speculate that Slan-DCs, at variance with CD34 $4^{+}$HSCs and monocytes [5,50], may not entirely depend upon the CXCR4/SDF- $1 \alpha$ axis for recirculation and homing into lymphoid organs and/or tissues. Our contention is backed by experiments with CD184-12G5 antibodies showing that CXCR4 levels are preserved on the surface of Slan-DCs, but not other leukocyte subsets, analyzed after the in vivo administration of G-CSF, when compared to G-CSF plus MZ, this likely favoring Slan-DC retention into tissues. The CD184-12G5 mAbs recognize an epitope involving the first and second extracellular domains of CXCR4, and inhibit MZ binding to CXCR4. A different anti-CXCR4 mAb, termed 1D9, binds to the $\mathrm{N}$ terminus of CXCR4 and is not affected by MZ [51]. In a phase 1/2 study of chemo-sensitization with MZ in relapsed or refractory acute myeloid leukemia, a decrease in CD18412G5 binding was observed from pre-treatment to 6 hours, followed by an increase from 6 to 24 hours, indicating CXCR4 blockade by MZ in vivo [52]. By contrast, labeling with CD184-1D9 after MZ treatment revealed an increased expression of CXCR4 between pretreatment and 6 hours, that remained elevated at 24. hours.

Finally, the frequency of CD1 $\mathrm{c}^{+} \mathrm{MDC} 1, \mathrm{CD} 141^{+} \mathrm{MDC} 2$ and plasmacytoid DCs [33] was unchanged in PB of donors treated with G-CSF, either alone or in combination with MZ. This is in agreement with previous reports showing no changes in the frequency of BDCA- $2^{+} \mathrm{DCs}$ in donors given G-CSF compared with baseline [36]. The TCR- $\alpha \beta / C D 19-$ depleted haploidentical grafts collected after the administration of G-CSF and MZ were highly enriched with MDC1, MDC2 and plasmacytoid DCs, when compared with normal BM samples. The role played by DCs in the regulation of human GVHD and GVL responses is the subject of intense investigation. Studies of BM transplantation have shown that high numbers of plasmacytoid DCs in the graft correlate with decreased chronic GVHD, at the expense of an increased incidence of leukemia relapse [53]. Conversely, the number of DCs in PB allografts may not predict DC reconstitution kinetics after transplantation or clinical outcome [54]. Importantly, low DC counts at time of engraftment have been associated with worse survival, increased incidence of relapse and higher incidence of grade II-IV acute GVHD [54].

Thus far, we have transplanted 23 children with nonmalignant disorders using TCR- $\alpha \beta / C D 19-$ depleted HSC grafts [26]. Primary graft failure occurred in 4 patients, with 3 patients developing skin-only grade 1 to 2 acute GVHD and no patient suffering from chronic GVHD. The cumulative incidence of transplantation-related mortality was $9.3 \%$. With a median follow-up of 18 months, 21 of 23 children are alive and disease-free, the 2-year probability of disease-free survival being $91.1 \%$ [26]. It remains to be determined whether and to what extent the DC content of our TCR- $\alpha \beta / C D 19$-depleted HSC grafts and, in particular, the remarkably high numbers of MDC1, MDC2 and plasmacytoid DCs infused correlate with infection control, GVHD and/or leukemia recurrence. 


\section{Conclusions}

Collectively, our study shows that MZ is highly effective at mobilizing mega-doses of CD34 ${ }^{+}$HSCs to be transplanted into haploidentical recipients. Furthermore, our data shed some light into the optimal clinical use of MZ, insofar differences in graft cellular composition after mobilization with G-CSF and MZ are expected to quantitatively and/or qualitatively influence the immune processes that occur after allogeneic HSCT.

\section{Additional files}

Additional file 1: Phenotype of circulating T-cell subsets after mobilization with G-CSF. PB samples from 21 randomly selected donors were analyzed for the relative frequency of TCR- $\alpha \beta / \gamma \delta$ T cells as well as naïve/memory T-cell subsets. Panel A: Lymphoid cells were gated based on their light scatter characteristics and on CD3 expression (P1), followed by the analysis of reciprocal $\alpha \beta$ and $\gamma \delta$-chain expression. Panel B: The frequency of $\mathrm{CD}^{+} \mathrm{T}$ cells/total lymphoid cells, a $\beta^{+} \mathrm{T}$ cells/total $\mathrm{CD} 3^{+} \mathrm{T}$ cells and $\gamma \delta^{+} T$ cells/total $\mathrm{CD}^{+} \mathrm{T}$ cells is shown before and after G-CSF administration. Bars indicate the median value recorded in 21 independent donor samples. Panels C-D: T-cell subsets were identified through labeling with anti-CD62L and anti-CD45RO mAb, which allowed the discrimination of naïve $T$ cells $\left(T_{N}\right)$ from central-memory $T$ cells $\left(T_{C M}\right)$, effector-memory $T$ cells $\left(T_{E M}\right)$ and terminally differentiated effectors. Bars indicate the median value recorded in 21 independent donor samples. TCR $=$ T-cell receptor.

Additional file 2: Phenotype of circulating B-cell subsets after mobilization with G-CSF. PB from 21 randomly selected donors were analyzed for the relative frequency of naïve/memory B-cell subsets. Panel A: mAbs directed against CD19, CD27, IgM and IgD were used to discriminate naïve B cells from memory B-cell subsets [30]. Panel B: The frequency of B-cell subsets/total CD19 ${ }^{+} B$ cells is shown before and after G-CSF administration. $N=$ naive $B$ cells $\left(C D 19^{+} C D 27^{-} \lg D^{+}\right) ; S-M=$ switched memory $B$ cells $\left(C D 19^{+} C D 27^{+} \operatorname{lgD}{ }^{-}\right)$; NS-M = non-switched memory $B$ cells $\left.\left(C D 19^{+} C D 27^{+} \operatorname{lgD}\right)^{+}\right) ; D N-M=$ double-negative memory $B$ cells $\left(\mathrm{CD} 19^{+} \mathrm{CD} 27^{-} \mathrm{lgD}{ }^{-}\right)$. Bars indicate the median value recorded in 21 independent donor samples.

Additional file 3: Circulating DC subsets after mobilization with G-CSF and plerixafor (MZ). PB samples from 40 randomly selected donors (24 GMs given G-CSF alone and 16 PMs receiving G-CSF + MZ) were analyzed for the relative frequency of major DC subsets. MDC1, MDC2 and plasmacytoid DCs were identified as detailed in Materials and Methods. Bars denote the median value. Before = baseline samples; after $=$ samples collected after HSC mobilization.

\section{Competing interests}

The authors declare that they have no competing interests.

\section{Authors' contributions}

SR, PF and VB performed the laboratory work for this study and analyzed the data; GLP, LA, EG and GC manipulated the haploidentical grafts; SC collected hematopoietic stem cells; LPB, BL and MGC cared for HSC donors; AB cared for patients; TC provided intellectual input; LM and FL provided intellectual input, analyzed the data and drafted the manuscript; SR conceived the study, participated in its design and coordination and drafted the manuscript. All authors read and approved the final manuscript.

\section{Acknowledgements}

These studies were supported by research funds to F.L. (PRIN-2010, '5 $\times$ Mille' Special Grant - AIRC, Ricerca Corrente 2014 - IRCCS Bambino Gesù Children's Hospital, Rome) and S.R. (PRIN-2012, grant \#2012NA9E9Y_004; Nuove Linee di Cellule Staminali Adulte - FILAS, Rome; Ricerca Corrente 2014 IRCCS Bambino Gesù Children's Hospital, Rome).

\section{Author details}

'Department of Pediatric Hematology/Oncology and Transfusion Medicine, IRCCS Bambino Gesù Children's Hospital, Rome, Italy. ${ }^{2}$ Pharmacy Service, IRCCS Bambino Gesù Children's Hospital, Rome, Italy. ${ }^{3}$ Istituto di Ricovero e Cura a Carattere Scientifico Giannina Gaslini, Genoa, Italy. ${ }^{4}$ Department of Pediatric Science, University of Pavia, Pavia, Italy. ${ }^{5}$ Current address: Division of Translational Medicine, Research Branch, Sidra Medical \& Research Centre, Doha, Qatar.

Received: 16 July 2014 Accepted: 23 August 2014

Published: 2 September 2014

\section{References}

1. Locatelli F, Vinti L, Palumbo G, Rossi F, Bertaina A, Mastronuzzi A, Bernardo ME, Rutella S, Dellabona P, Giorgiani G, Moretta A, Moretta L: Strategies to optimize the outcome of children given T-cell depleted HLAhaploidentical hematopoietic stem cell transplantation. Best Pract Res Clin Haematol 2011, 24:339-349.

2. Martelli MF, Di lanni M, Ruggeri L, Pierini A, Falzetti F, Carotti A, Terenzi A, Reisner Y, Aversa F, Falini B, Velardi A: "Designed" grafts for HLAhaploidentical stem cell transplantation. Blood 2014, 123:967-973.

3. To LB, Levesque JP, Herbert KE: How I treat patients who mobilize hematopoietic stem cells poorly. Blood 2011, 118:4530-4540.

4. DiPersio JF, Uy GL, Yasothan U, Kirkpatrick P: Plerixafor. Nat Rev Drug Discov 2009, 8:105-106

5. Rutella S, Pierelli L, Bonanno G, Scambia G, Leone G, Rumi C: Homogeneous expression of CXC chemokine receptor 4 (CXCR4) on G-CSF-mobilized peripheral blood CD34+ cells. Blood 2000, 95:4015-4016.

6. DiPersio JF, Micallef IN, Stiff PJ, Bolwell BJ, Maziarz RT, Jacobsen E, Nademanee A, McCarty J, Bridger G, Calandra G, Investigators: Phase III prospective randomized double-blind placebo-controlled trial of plerixafor plus granulocyte colony-stimulating factor compared with placebo plus granulocyte colony-stimulating factor for autologous stem-cell mobilization and transplantation for patients with nonHodgkin's lymphoma. J Clin Oncol 2009, 27:4767-4773.

7. Nademanee AP, DiPersio JF, Maziarz RT, Stadtmauer EA, Micallef IN, Stiff PJ, Hsu FJ, Bridger G, Bolwell BJ: Plerixafor plus granulocyte colonystimulating factor versus placebo plus granulocyte colony-stimulating factor for mobilization of $\mathrm{CD} 34^{+}$hematopoietic stem cells in patients with multiple myeloma and low peripheral blood $\mathrm{CD}_{3} 4^{+}$cell count: results of a subset analysis of a randomized trial. Biol Blood Marrow Transplant 2012, 18:1564-1572.

8. Steinman RM, Hawiger D, Nussenzweig MC: Tolerogenic dendritic cells. Annu Rev Immunol 2003, 21:685-711.

9. Ziegler-Heitbrock L, Ancuta P, Crowe S, Dalod M, Grau V, Hart DN, Leenen PJ, Liu YJ, MacPherson G, Randolph GJ, Scherberich J, Schmitz J, Shortman K, Sozzani S, Strobl H, Zembala M, Austyn JM, Lutz MB: Nomenclature of monocytes and dendritic cells in blood. Blood 2010, 116:e74-e80.

10. Jongbloed SL, Kassianos AJ, McDonald KJ, Clark GJ, Ju X, Angel CE, Chen CJ, Dunbar PR, Wadley RB, Jeet V, Vulink AJ, Hart DN, Radford KJ: Human $\mathrm{CD}_{141^{+}}(\mathrm{BDCA}-3)^{+}$dendritic cells (DCs) represent a unique myeloid DC subset that cross-presents necrotic cell antigens. J Exp Med 2010, 207:1247-1260.

11. Bachem A, Guttler S, Hartung E, Ebstein F, Schaefer M, Tannert A, Salama A, Movassaghi K, Opitz C, Mages HW, Henn V, Kloetzel PM, Gurka S, Kroczek RA: Superior antigen cross-presentation and XCR1 expression define human $\mathrm{CD} 11 \mathrm{c}^{+} \mathrm{CD} 141^{+}$cells as homologues of mouse $\mathrm{CD} 8^{+}$dendritic cells. J Exp Med 2010, 207:1273-1281.

12. Nizzoli G, Krietsch J, Weick A, Steinfelder S, Facciotti F, Gruarin P, Bianco A, Steckel B, Moro M, Crosti M, Romagnani C, Stolzel K, Torretta S, Pignataro L, Scheibenbogen C, Neddermann P, De Francesco R, Abrignani S, Geginat J: Human CD1c ${ }^{+}$dendritic cells secrete high levels of IL-12 and potently prime cytotoxic T-cell responses. Blood 2013, 122:932-942.

13. Anderlini P, Champlin RE: Biologic and molecular effects of granulocyte colony-stimulating factor in healthy individuals: recent findings and current challenges. Blood 2008, 111:1767-1772.

14. Rutella S, Zavala F, Danese S, Kared H, Leone G: Granulocyte colonystimulating factor: a novel mediator of T cell tolerance. J Immunol 2005, 175:7085-7091.

15. Pan L, Delmonte J, Jalonen CK, Ferrara JL: Pretreatment of donor mice with granulocyte colony-stimulating factor polarizes donor $T$ 
lymphocytes toward type-2 cytokine production and reduces severity of experimental graft-versus-host disease. Blood 1995, 86:4422-4429.

16. Sloand EM, Kim S, Maciejewski JP, Van Rhee F, Chaudhuri A, Barrett J, Young NS: Pharmacologic doses of granulocyte colony-stimulating factor affect cytokine production by lymphocytes in vitro and in vivo. Blood 2000, 95:2269-2274

17. Rutella S, Pierelli L, Bonanno G, Sica S, Ameglio F, Capoluongo E, Mariotti A, Scambia G, d'Onofrio G, Leone G: Role for granulocyte colony-stimulating factor in the generation of human T regulatory type 1 cells. Blood 2002, 100:2562-2571.

18. Bonanno G, Procoli A, Mariotti A, Corallo M, Perillo A, Danese S, De Cristofaro R, Scambia G, Rutella S: Effects of pegylated G-CSF on immune cell number and function in patients with gynecological malignancies. J Transl Med 2010, 8:114.

19. Rutella S, Bonanno G, Pierelli L, Mariotti A, Capoluongo E, Contemi AM, Ameglio F, Curti A, De Ritis DG, Voso MT, Perillo A, Mancuso S, Scambia G, Lemoli RM, Leone G: Granulocyte colony-stimulating factor promotes the generation of regulatory DC through induction of IL-10 and IFN-a. Eur J Immunol 2004, 34:1291-1302.

20. Rutella S, Bonanno G, Procoli A, Mariotti A, de Ritis DG, Curti A, Danese S, Pessina G, Pandolfi S, Natoni F, Di Febo A, Scambia G, Manfredini R, Salati S, Ferrari S, Pierelli L, Leone G, Lemoli RM: Hepatocyte growth factor favors monocyte differentiation into regulatory interleukin (IL)- $10^{++} \mathrm{IL}-12^{\text {low/neg }}$ accessory cells with dendritic-cell features. Blood 2006, 108:218-227.

21. Arpinati M, Green CL, Heimfeld S, Heuser JE, Anasetti C: Granulocyte-colony stimulating factor mobilizes T helper 2-inducing dendritic cells. Blood 2000, 95:2484-2490

22. Hauge AW, Haastrup EK, Sengelov H, Minulescu L, Dickmeiss E, FischerNielsen A: Addition of plerixafor for $\mathrm{CD}_{3} 4^{+}$cell mobilization in six healthy stem cell donors ensured satisfactory grafts for transplantation. Transfusion 2014, 54:1055-1058.

23. Devine SM, Vij R, Rettig M, Todt L, McGlauchlen K, Fisher N, Devine H, Link $D C$, Calandra G, Bridger G, Westervelt P, Dipersio JF: Rapid mobilization of functional donor hematopoietic cells without G-CSF using AMD3100, an antagonist of the CXCR4/SDF-1 interaction. Blood 2008, 112:990-998.

24. Neumann T, Kruger WH, Busemann C, Kiefer T, Dolken G: Successful mobilization of PBSCs in a healthy volunteer donor by addition of plerixafor after failure of mobilization with G-CSF alone. Bone Marrow Transplant 2011, 46:762-763.

25. Gaugler B, Arbez J, Legouill S, Tiberghien P, Moreau P, Derenne S, Saas P, Mohty M: Characterization of peripheral blood stem cell grafts mobilized by granulocyte colony-stimulating factor and plerixafor compared with granulocyte colony-stimulating factor alone. Cytotherapy 2013, 15:861-868

26. Bertaina A, Merli P, Rutella S, Pagliara D, Bernardo ME, Masetti R, Pende D, Falco M, Handgretinger R, Moretta F, Lucarelli B, Brescia LP, Li Pira G, Testi M, Cancrini C, Kabbara N, Carsetti R, Finocchi A, Moretta A, Moretta L, Locatelli F: HLA-haploidentical stem cell transplantation after removal of $a \beta^{+} T$ and $B$ cells in children with non-malignant disorders. Blood 2014, 124:822-826.

27. Pierelli L, Maresca M, Piccirillo N, Pupella S, Gozzer M, Foddai ML, Vacca M, Adorno G, Coppetelli U, Paladini U: Accurate prediction of autologous stem cell apheresis yields using a double variable-dependent method assures systematic efficiency control of continuous flow collection procedures. Vox Sang 2006, 91:126-134.

28. Whitby A, Whitby L, Fletcher M, Reilly JT, Sutherland DR, Keeney M, Barnett D: ISHAGE protocol: are we doing it correctly? Cytometry B Clin Cytom 2012, 82:9-17.

29. Schumm M, Lang P, Bethge W, Faul C, Feuchtinger T, Pfeiffer M, Vogel W, Huppert V, Handgretinger R: Depletion of T-cell receptor $\alpha \beta$ and CD19 positive cells from apheresis products with the CliniMACS device. Cytotherapy 2013, 15:1253-1258.

30. Jackson SM, Wilson PC, James JA, Capra JD: Human B cell subsets. Adv Immunol 2008, 98:151-224.

31. Sallusto F, Lenig D, Forster R, Lipp M, Lanzavecchia A: Two subsets of memory T lymphocytes with distinct homing potentials and effector functions. Nature 1999, 401:708-712.

32. Della Chiesa M, Falco M, Podesta M, Locatelli F, Moretta L, Frassoni F, Moretta A: Phenotypic and functional heterogeneity of human NK cells developing after umbilical cord blood transplantation: a role for human cytomegalovirus? Blood 2012, 119:399-410.
33. Dzionek A, Fuchs A, Schmidt P, Cremer S, Zysk M, Miltenyi S, Buck DW, Schmitz J: BDCA-2, BDCA-3, and BDCA-4: three markers for distinct subsets of dendritic cells in human peripheral blood. J Immunol 2000, 165:6037-6046.

34. Schakel K, Kannagi R, Kniep B, Goto Y, Mitsuoka C, Zwirner J, Soruri A, von Kietzell M, Rieber E: 6-Sulfo LacNAc, a novel carbohydrate modification of PSGL-1, defines an inflammatory type of human dendritic cells. Immunity 2002, 17:289-301.

35. Levesque JP, Hendy J, Takamatsu Y, Simmons PJ, Bendall L: Disruption of the CXCR4/CXCL12 chemotactic interaction during hematopoietic stem cell mobilization induced by GCSF or cyclophosphamide. J Clin Invest 2003, 111:187-196.

36. Arpinati M, Chirumbolo G, Urbini B, Martelli V, Stanzani M, Falcioni S, Bonifazi F, Bandini G, Tura S, Baccarani M, Rondelli D: Use of anti-BDCA-2 antibody for detection of dendritic cells type-2 (DC2) in allogeneic hematopoietic stem cell transplantation. Bone Marrow Transplant 2002, 29:887-891.

37. Locatelli F, Merli P, Rutella S: At the Bedside: Innate immunity as an immunotherapy tool for hematological malignancies. J Leukoc Biol 2013, 94:1141-1157

38. Hainz U, Obexer P, Winkler C, Sedlmayr P, Takikawa O, Greinix H, Lawitschka A, Potschger U, Fuchs D, Ladisch S, Heitger A: Monocyte-mediated T-cell suppression and augmented monocyte tryptophan catabolism after human hematopoietic stem-cell transplantation. Blood 2005, 105:4127-4134.

39. Foley B, Cooley S, Verneris MR, Curtsinger J, Luo X, Waller EK, Weisdorf DJ, Miller JS: NK cell education after allogeneic transplantation: dissociation between recovery of cytokine-producing and cytotoxic functions. Blood 2011, 118:2784-2792.

40. Hansel A, Gunther C, Ingwersen J, Starke J, Schmitz M, Bachmann M, Meurer M, Rieber EP, Schakel K: Human slan (6-sulfo LacNAc) dendritic cells are inflammatory dermal dendritic cells in psoriasis and drive strong $\mathrm{TH} 17 /$ TH1 T-cell responses. J Allergy Clin Immunol 2011, 127:787-794. e781-789.

41. Kared $\mathrm{H}$, Masson A, Adle-Biassette H, Bach JF, Chatenoud L, Zavala F: Treatment with granulocyte colony-stimulating factor prevents diabetes in NOD mice by recruiting plasmacytoid dendritic cells and functional $\mathrm{CD}^{+} \mathrm{CD}^{2} 5^{+}$regulatory T-cells. Diabetes 2005, 54:78-84.

42. Lundqvist A, Smith AL, Takahashi Y, Wong S, Bahceci E, Cook L, Ramos C, Tawab A, McCoy JP Jr, Read EJ, Khuu HM, Bolan CD, Joo J, Geller N, Leitman SF, Calandra G, Dunbar C, Kurlander R, Childs RW: Differences in the phenotype, cytokine gene expression profiles, and in vivo alloreactivity of T cells mobilized with plerixafor compared with G-CSF. J Immunol 2013, 191:6241-6249.

43. MacDonald KP, Le Texier L, Zhang P, Morris H, Kuns RD, Lineburg KE, Leveque L, Don AL, Markey KA, Vuckovic S, Bagger FO, Boyle GM, Blazar BR, Hill GR: Modification of T cell responses by stem cell mobilization requires direct signaling of the T cell by G-CSF and IL-10. J Immunol 2014, 192:3180-3189.

44. Morris ES, MacDonald KP, Hill GR: Stem cell mobilization with G-CSF analogs: a rational approach to separate GVHD and GVL? Blood 2006, 107:3430-3435.

45. Sunami K, Teshima T, Nawa Y, Hiramatsu Y, Maeda Y, Takenaka K, Shinagawa K, Ishimaru F, lkeda K, Niiya K, Harada M: Administration of granulocyte colony-stimulating factor induces hyporesponsiveness to lipopolysaccharide and impairs antigen-presenting function of peripheral blood monocytes. Exp Hematol 2001, 29:1117-1124.

46. Frankenberger M, Hofer TP, Marei A, Dayyani F, Schewe S, Strasser C, Aldraihim A, Stanzel F, Lang R, Hoffmann R, Prazeres da Costa O, Buch T, Ziegler-Heitbrock L: Transcript profiling of CD16-positive monocytes reveals a unique molecular fingerprint. Eur J Immunol 2012, 42:957-974.

47. Cros J, Cagnard N, Woollard K, Patey N, Zhang SY, Senechal B, Puel A, Biswas SK, Moshous D, Picard C, Jais JP, D'Cruz D, Casanova JL, Trouillet C, Geissmann F: Human CD14 ${ }^{\mathrm{dim}}$ monocytes patrol and sense nucleic acids and viruses via TLR7 and TLR8 receptors. Immunity 2010, 33:375-386.

48. Storek J, Espino G, Dawson MA, Storer B, Flowers ME, Maloney DG: Low B-cell and monocyte counts on day 80 are associated with high infection rates between days 100 and 365 after allogeneic marrow transplantation. Blood 2000, 96:3290-3293.

49. Baumeister SH, Holig K, Bornhauser M, Meurer M, Rieber EP, Schakel K: G-CSF mobilizes slanDCs (6-sulfo LacNAc dendritic cells) with a high proinflammatory capacity. Blood 2007, 110:3078-3081. 
50. Dar A, Schajnovitz A, Lapid K, Kalinkovich A, Itkin T, Ludin A, Kao WM, Battista M, Tesio M, Kollet O, Cohen NN, Margalit R, Buss EC, Baleux F, Oishi S, Fujii N, Larochelle A, Dunbar CE, Broxmeyer HE, Frenette PS, Lapidot T: Rapid mobilization of hematopoietic progenitors by AMD3100 and catecholamines is mediated by CXCR4-dependent SDF-1 release from bone marrow stromal cells. Leukemia 2011, 25:1286-1296.

51. Gerlach LO, Skerlj RT, Bridger GJ, Schwartz TW: Molecular interactions of cyclam and bicyclam non-peptide antagonists with the CXCR4 chemokine receptor. J Biol Chem 2001, 276:14153-14160.

52. Uy GL, Rettig MP, Motabi IH, McFarland K, Trinkaus KM, Hladnik LM, Kulkarni S, Abboud CN, Cashen AF, Stockerl-Goldstein KE, Vij R, Westervelt P, DiPersio JF: A phase $1 / 2$ study of chemosensitization with the CXCR4 antagonist plerixafor in relapsed or refractory acute myeloid leukemia. Blood 2012, 119:3917-3924.

53. Waller EK, Rosenthal H, Jones TW, Peel J, Lonial S, Langston A, Redei I, Jurickova I, Boyer MW: Larger numbers of $\mathrm{CD}_{4}^{\text {bright }}$ dendritic cells in donor bone marrow are associated with increased relapse after allogeneic bone marrow transplantation. Blood 2001, 97:2948-2956.

54. Reddy V, Iturraspe JA, Tzolas AC, Meier-Kriesche HU, Schold J, Wingard JR: Low dendritic cell count after allogeneic hematopoietic stem cell transplantation predicts relapse, death, and acute graft-versus-host disease. Blood 2004, 103:4330-4335.

55. Ziegler-Heitbrock L, Hofer TP: Toward a refined definition of monocyte subsets. Front Immunol 2013, 4:23.

doi:10.1186/s12967-014-0240-z

Cite this article as: Rutella et al: Mobilization of healthy donors with plerixafor affects the cellular composition of T-cell receptor (TCR)-aß/ CD19-depleted haploidentical stem cell grafts. Journal of Translational Medicine 2014 12:240

\section{Submit your next manuscript to BioMed Central and take full advantage of:}

- Convenient online submission

- Thorough peer review

- No space constraints or color figure charges

- Immediate publication on acceptance

- Inclusion in PubMed, CAS, Scopus and Google Scholar

- Research which is freely available for redistribution 